\title{
ROLE OF CARBOXYL GROUPS IN THE SECONDARY STRUCTURE AND FUNCTION OF STURGEON GONADOTROPIN
}

\author{
Henriks Zenkevičs*, Ilze Vosekalna**, and Vija Vose* \\ * Institute of Biology, University of Latvia, Miera iela 3, Salaspils, LV-2169, LATVIA \\ e-mail: zenkevics@lubi.edu.Iv \\ ** Latvian Institute of Organic Synthesis, Aizkraukles iela 21, Rīga, LV-1006, LATVIA
}

Contributed by Henriks Zenkevičs

\begin{abstract}
Free negatively charged carboxyl groups were selectively modified (neutralised) in sturgeon (Acipenser güldenstädti Br.) gonadotropic hormone (GTH) $\alpha$ and $\beta$ subunits. Eleven free carboxyl groups, three in the $\alpha$ and eight in the $\beta$ subunit, were neutralised by reaction with glycine ethyl ester. Investigation of reassociated $\alpha-\beta$ dimers (recombinants) comprising one or both modified subunits showed that specific hormonal activity was completely lost while immunoreactivity was lowered in comparison with that of the standard $\alpha-\beta$ dimer. CD-spectroscopy of the modified subunits did not indicate any considerable changes in their spatial structure. A conclusion was made that free $\mathrm{COOH}$ groups of GTH were important as bearers of the negative charge necessary for the hormone activity on the level of the hormone-specific membrane receptors.
\end{abstract}

Key words: fish gonadotropic hormone, subunits, chemical modification, secondary structure, biological function, CD-spectroscopy.

\section{INTRODUCTION}

Biochemical and functional properties of fish, particularly sturgeon fish gonadotropic hormone $(\mathrm{GTH})$, are considerably less studied than that of mammalian gonadotropins. The heterodimeric molecule $(26 \mathrm{kDa})$ of sturgeon $\mathrm{GTH}$, like mammalian gonadotropins, is built of two complementary non-covalently bonded $\alpha$ and $\beta$ subunits ( $\alpha$ GTH and $\beta G T H)$ (Zenkevičs, 1994). Hormonal and immunological function typical for the hormone is expressed only in the $\alpha-\beta$ complex formed after noncovalent self-association of the separate $\alpha$ and $\beta$ subunits into heterodimeric molecular structure (Зенкевич, 1992). GTH dimer reassociated in vitro from the counterpart subunits usually indicates up to $100 \%$ of immunoreactivity and about $70 \%$ of hormonal function typical of the standard intact hormone (Зенкевич, 1992).

As a member of the pituitary glycoprotein hormone family, sturgeon GTH contains an asparagine-linked sugar moiety corresponding to $30 \%$ of the hormone molecular mass (Зенкевич и др., 1992). The complicated structure of gonadotropin prevents the synthesis of its molecular analogues. Therefore, selective chemical modification can be used to obtain the hormone or its subunit analogues with potentially different properties. The selective chemical modification of the functionally significant side chains radicals in sturgeon GTH dimer structure and in its individual subunits and subsequent analysis of its physico-chemical and biological properties has been considered as an efficient instrument for studying the correlative relationship between the molecular structure and specific biological function of the hormone (Zenkevičs, 1994).

The aim of the present work was to employ selective chemical modification of the accessible free negatively charged $\mathrm{COOH}$ groups in the individual $\alpha$ and $\beta$ subunits to elucidate their role both in the biological function of the restored $\alpha-\beta$ dimer molecule and in the maintaining of the secondary structure of the subunits.

\section{MATERIALS AND METHODS}

A highly purified GTH was isolated from acetone-dried pituitary glands of the fish by means of a standard procedure using gel-filtration on Sephadex and ion-exchange chromatography on DEAE-cellulose DE-32 (Whatman) columns as described earlier (Зенкевич, 1992).

Individual $\alpha$ and $\beta$ subunits of GTH were isolated by ionexchange chromatography on SE-Sephadex C-25 in 0.025 $\mathrm{M}$ acetate buffer at $\mathrm{pH} 4.9$, after GTH dissociation into subunits in $8 \mathrm{M}$ urea according to Hennen et al. (1971). Self-reassociation or recombination of the counterpart subunits was carried out in saline $(0.9 \% \mathrm{NaCl})$ at room temperature $(12 \mathrm{~h})$ at a total protein concentration of about $0.2 \%$, using the subunits in an equimolar ratio. Free $\mathrm{COOH}$ groups of the separate subunits were modified by glycine ethyl ester (Gly-OEt. $\mathrm{HCl})$ in the presence of water soluble carbodiimide (1-ethyl-3(3-dimethylaminopropyl) carbodiimide) (Serva) at $\mathrm{pH} 4.8$ in distilled water for $30 \mathrm{~min}$ at 
room temperature according to the standardised procedure described earlier (Faith and Pierce, 1975; Зенкевич, 1992). In such a way free carboxyl groups of the subunits were converted to their O-glycine ethyl esters. Reaction was stopped and modified preparations were separated from the reaction by-products on minicolumns of Sephadex C-25 in $2 \%$ acetic acid and lyophilised. The number of modified $\mathrm{COOH}$ groups was determined by analysing the amino acid composition (Mikrotehna Praha, Czech Rep.).

Double immunodiffusion tests in 1\% agar gel (Bacto-agar Difco, U.S.A.) in veronal buffer (ionic strength $0.05, \mathrm{pH}$ 8.6) were performed by a classical procedure (Ouchterlony, 1958) using polyclonal monovalent antisera raised in rabbits against standard sturgeon GTH. The relative immunoreactivity as a percent of the standard and modified preparations was calculated as the inverse proportion between the numbers of active double dilutions.

The frog Rana temporaria L. oocyte maturation test (Thornton, 1971) was used to evaluate the hormonal activity of the reassociated $\alpha-\beta$ dimers comprising $\mathrm{COOH}-$ modified subunits. The activity was expressed as the minimal dose of the tested preparation that produced $50 \%$ test-oocyte in vitro maturation (D50).

CD spectra of the standard and $\mathrm{COOH}$-modified subunits were registered on a Jasco J-710 spectropolarimeter over the wavelength range from 180 to $250 \mathrm{~nm}$ at $22-25^{\circ} \mathrm{C}$, in phosphate buffer, $\mathrm{pH}$ 7.0. The spectropolarimeter was calibrated by epiandrosterone and 10-camphor-sulphonic acid. For recording of spectra, $0.1-0.01 \mathrm{~cm}$ Helma quartz cells were used. The concentration of protein in the solution was $10^{-3}-10^{-4} \mathrm{M}$. CD data are given in units of molar ellipticity per amino acid residue of an average relative molecular mass 108. The content of various secondary structures in the subunit preparations was calculated using the CDPro CONTINLL programme (Sreerama et al., 1999; Whitmore and Wallace, 2004; Lees et al., 2006). In our case the CD spectra of 29-48 proteins were used for calculation of the secondary structure elements.

\section{RESULTS}

The standard GTH molecule contains a total of 28 Asx and Glx residues (Зенкевич, 1992). Amino acid analyses of the carboxyl-modified (etoxyglycylated) subunits showed that the 11 negatively charged free carboxyls, three of which are in the $\alpha \mathrm{GTH}$ and eight in the $\beta \mathrm{GTH}$, were modified and converted to neutral ones (11 additional glycines were found). Also, it was found by additional amino acid analysis during the modification course that the number of modified $\mathrm{COOH}$ groups (degree of modification) in the separate subunits did not increase after 20 minutes since the beginning of the modification.

The modified subunits were cross-reassociated or recombined with the standard native counterparts to produce $\alpha-\beta$ dimers in which one or both native subunits were replaced by the modified ones: $\alpha_{\text {st }}+\beta_{\text {mod }} ; \alpha_{\text {mod }}+\beta_{\text {st }}$ and $\alpha_{\text {mod }}+$ $\beta_{\text {mod. }}$ This approach was used to elucidate the possible structure-functional role of negatively charged $\mathrm{COOH}$ groups of the particular subunits in the specific hormonal function and immunoreactivity of the modified molecular structure of the hormone in comparison with that of the control recombinant of the standard subunits $\alpha_{\mathrm{st}}+\beta_{\mathrm{st}}$ (Table 1).

Table 1

BIOLOGICAL PROPERTIES OF REASSOCIATED $\alpha-\beta$ DIMERS COMPRISING COOH-MODIFIED SUBUNITS

\begin{tabular}{lccc}
\hline \multicolumn{1}{c|}{ Preparation } & Anti-serum & $\begin{array}{r}\text { Immuno- } \\
\text { reactivity, } \%\end{array}$ & $\begin{array}{r}\text { Hormonal } \\
\text { activity, } \%\end{array}$ \\
\hline$\alpha$ st $+\beta$ st & GTH & 100 & 100 \\
$\alpha$ st $+\beta$ mod & GTH & 75 & 0 \\
$\alpha$ mod $+\beta$ st & GTH & 50 & 0 \\
$\alpha$ mod $+\beta$ mod & GTH & 0 & 0 \\
\multicolumn{2}{l}{ st - standard; mod. - modified COOH-groups }
\end{tabular}

The comparison of the recombined dimers in double immunodiffusion tests with sturgeon GTH antiserum indicated that the substitution of the native $\beta$ GTH by the $\mathrm{COOH}$-modified one lowered immunoreactivity by $25 \%$ while the similar substitution of the $\alpha \mathrm{GTH}$ turned out to be more critical and resulted in the reduction of immunoactivity of the modified dimer by half in comparison with that of the control recombinant. The dimer comprising both modified subunits was completely inactive (Table 1).

Evaluation of hormonal function showed that all tested recombinants containing the modified subunits were inactive in the specific highly sensitive sturgeon GTH biotest system on frog oocytes (Table 1).

CD spectra of the subunits shown in Figure 1 indicate that the conformation of the standard subunits $\alpha \mathrm{GTH}$ and $\beta \mathrm{GTH}$ is characterised by a negative band around 193-197 nm and a shoulder (or two minor negative bands) at 205 and $215 \mathrm{~nm}$ that is well expressed for $\alpha$ GTH and weaker for $\beta$ GTH. The negative Cotton effect around $195 \mathrm{~nm}$ is close to the well-known negative band of the random coil at $198 \mathrm{~nm}$ while the shoulder and the negative band (around 205 and $215 \mathrm{~nm}$ ) could arise from the significant contribution of the $\beta$-structures, and the minor contribution of the $\alpha$-helix (Lees et al., 2006).

Results of the calculation of the content of various secondary structures shown in Table 1 allowed us to conclude that the spatial structures of the standard $\alpha$ and $\beta$ subunits were quite similar. The content of the secondary structures of $\mathrm{COOH}$-modified and standard $\beta$ subunit is practically similar while a slight decrease in the $\alpha$-helix and an increase in the content of "random coil" structures was found in the modified $\alpha$ subunit (Fig. 1A, Table 2), i.e. the spatial structure of this subunit was slightly distorted ( $\mathrm{R} \sim 58 \%$ ). 
A

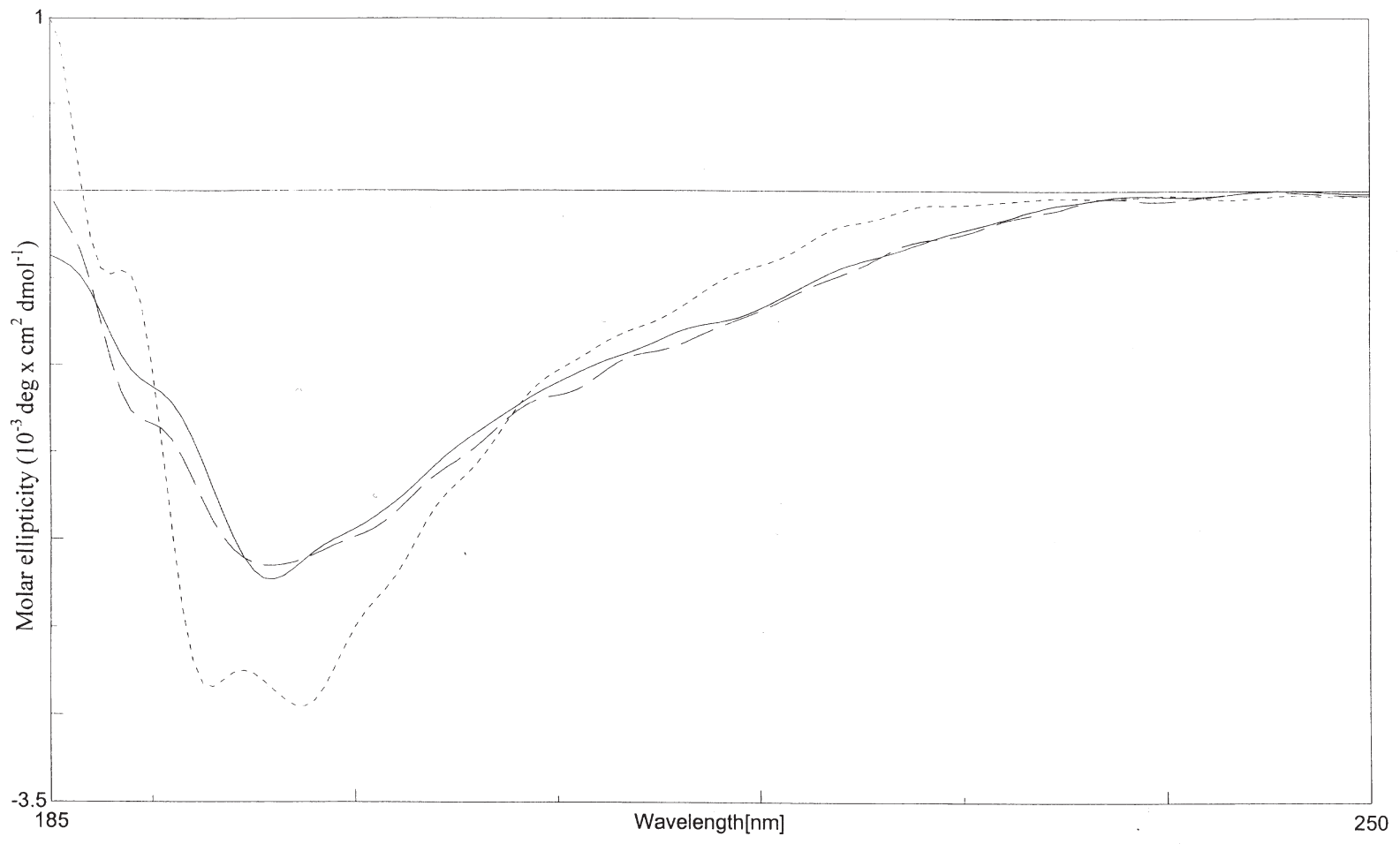

B

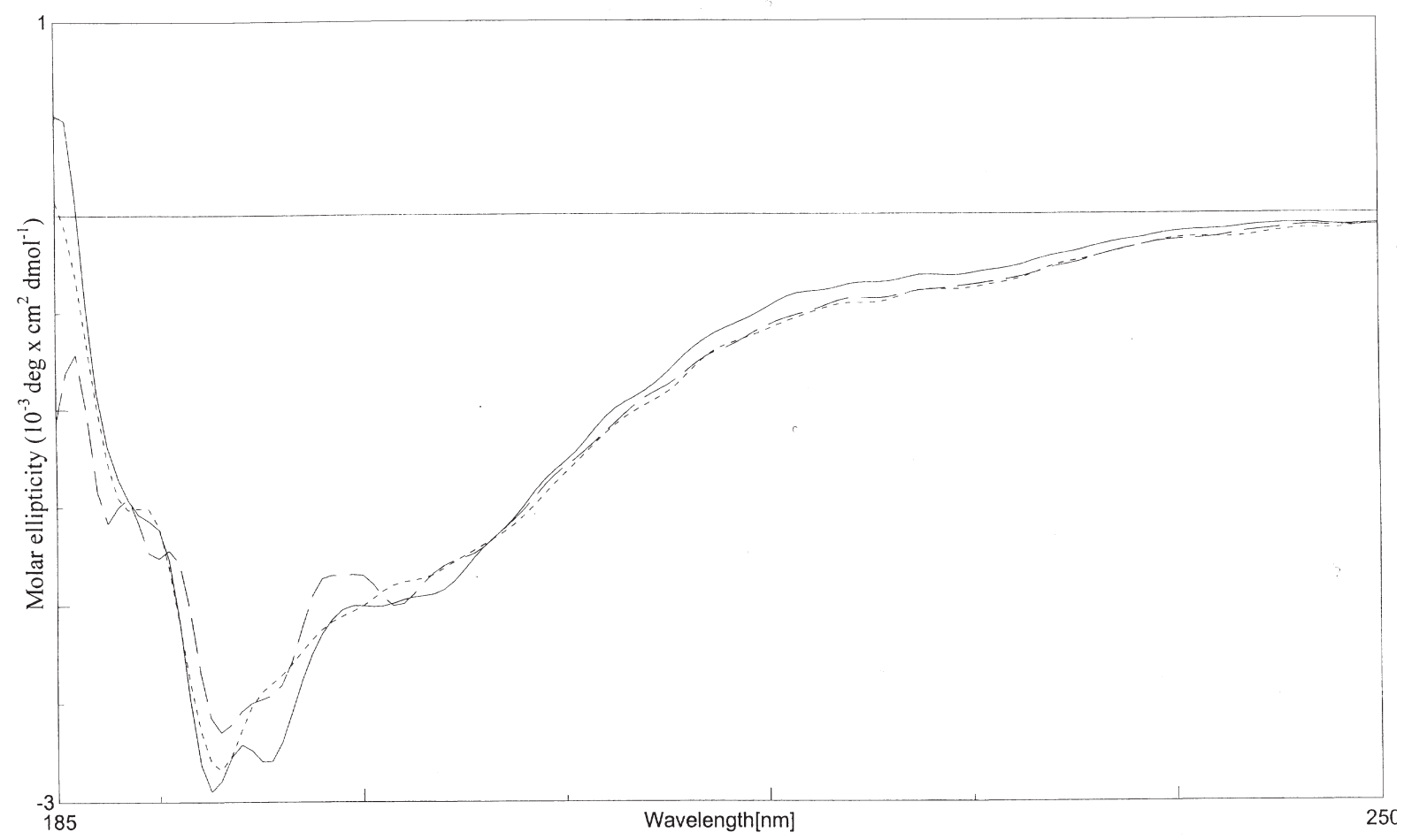

Fig. 1. A: CD spectra of sturgeon GTH $\alpha$ st (—), $\alpha \bmod (---)$, $\alpha \bmod (--)$ repeated; B: CD spectra of sturgeon GTH $\beta$ st $(-)$, $\beta \bmod (--)$, $\beta \bmod (----)$ repeated.

\section{DISCUSSION}

The modification (neutralisation) of eight free $\mathrm{COOH}$ groups of $\beta$ GTH did not produce any shifts in its secondary structure in comparison with that of the intact standard subunit (Fig. 1B, Table 2). This indicated that the neutralised negatively charged side chain radicals were not critical for the native three-dimensional structure of the subunit and that it still could recognise active sites of the standard $\alpha \mathrm{GTH}$ to form stereospecifically stable and typical for the hormone $\alpha-\beta$ dimer molecule $\alpha$ st $+\beta$ mod. Hormone-specific immunoreactivity of the modified recombinant was lower by $25 \%$ in comparison with that of the control (Table 1). Substitution of the standard $\alpha$ subunit with the modified an- 
Table 2

CONTENT OF SECONDARY STRUCTURE ELEMENTS (\%) OF STANDARD AND COOH-MODIFIED $\alpha$ AND $\beta$ SUBUNITS

\begin{tabular}{l|c|c|c|c}
\hline \multicolumn{1}{c}{ Preparation } & $\alpha^{*}$ & $\beta^{*}$ & $\beta \mathrm{t}^{*}$ & $\mathrm{R}^{*}$ \\
\hline$\beta_{\text {st }}$ & 1.9 & 24.7 & 15.2 & 58.2 \\
$\beta_{\text {mod }}$ & 2.3 & 24.2 & 14.3 & 59.2 \\
$\alpha_{\text {st }}$ & 2.8 & 29.1 & 15.9 & 52.2 \\
$\alpha_{\text {mod }}$ & 1.8 & 26.4 & 14.1 & 57.7
\end{tabular}

${ }^{*} \alpha, \alpha$-helix; $\beta, \beta$-turn; $\mathrm{R}$, random coil; st, standard; mod, modified COOH-groups.

alogue resulted in more pronounced loss of immunoreactivity reaching $50 \%$.

The antigenic structure of sturgeon GTH is built of both subunits (Зенкевич и др., 1987). Each of the counterpart subunits may induce formation of the hormone-specific conformational antigenic determinants due to interconversions brought about during the counterpart subunit interaction or complementation into $\alpha-\beta$ dimer structure typical of the hormone. As previously shown (Зенкевич, 1992), sturgeon $\beta \mathrm{GTH}$ has a rigid polypeptide chain (six S-S-bonds) with receptor-specific $\alpha \mathrm{GTH}$ binding domains playing a dominant role as a core in the folding of the correct and hormone-specific spatial structure of $\alpha \mathrm{GTH}$ (two S-S-bonds) and of the heterodimer structure of the whole hormone molecule. The results are in good agreement with our earlier findings (Zenkevičs et al., 1999; 2003) indicating the structural rigidity of the $\beta \mathrm{GTH}$ and its role in sustaining of the specific biological function of the hormone.

The comparative evaluation of hormonal activity showed (Table 1) that all tested recombinants containing one or both $\mathrm{COOH}$-modified subunits were completely inactive.

This quite clearly shows that $\mathrm{COOH}$ groups have a direct importance for the specific hormonal function and are much less critical for immunologic activity of the hormone. Ability of the standard GTH antiserum to interact with the recombinants $\alpha s t+\beta \bmod$ and $\alpha \bmod +\beta$ st in the specific immunodiffusion tests indicated that the modification of the carboxyl groups on either of the subunits did not prevent the formation of the $\alpha-\beta$ structures recognisable by the standard GTH antibodies. However, reassociation of $\mathrm{COOH}-$ modified counterpart subunits $\alpha_{\text {mod }}+\beta_{\text {mod }}$ (Table 1) may lead to a considerable redistribution of the surface charge of the subunits, which may cause an indirect impact on the configuration and complementarity of the sites responsible for subunit-subunit interaction (reassociation), dimer stability and stereospecificity of its antigenic determinant groups responsible for antigen-antibody relationships. This may account for the lack of the specific hormonal function and immunoactivity of the dimer.

However, these data allow to conclude that the modified $\mathrm{COOH}$ groups are not directly involved in the subunitsubunit interactions and in the formation of the three- dimensional functionally active structure of the recombinants.

Thus, the conformation of the investigated recombinants, comprising one $\mathrm{COOH}-$ modified subunit, is closely related to that of the standard GTH, since an antigen-antibody immunospecific interaction necessitates a close stereospecific fit between the antigenic determinant groups of the modified recombinants as the standard GTH molecular analogues and active sites of the antibodies rised against standard GTH. Concerning the hormonal activity, it is relevant to remind here that even minimal distortions of the three-dimensional structure of protein-like bioregulators may alter their functional (effector) group disposition on the molecular surface causing considerable shifts in their ability to interact stereospecifically with the hormone-specific receptor sites of the cell membrane to induce the biological effects. The results also support our previous findings that the immunological properties of sturgeon GTH are much less vulnerable than its specific hormonal function (Зенкевич, 1992; Зенкевич и др., 1992).

CD studies showed that the removal of negative charges on native subunits did not cause any appreciable distortion in the spatial structure of the $\beta-G T H$ (Fig. 1B) while some changes occurred in the content of $\alpha$-helix $(1.8 \%)$ and in "random coil" or disordered structures $(\mathrm{R} \sim 58 \%)$ of the modified $\alpha$ subunit. (Fig. 1A, Table 2).

These studies clearly show that a total of 11 negatively charged free $\mathrm{COOH}$ groups are located on the surface of both subunits and are easily accessible for the modification. The neutralised carboxyl groups did not play any considerable role in sustaining the spatial structure of the individual subunits. CD-spectroscopy data quite clearly showed that the neutralisation of the negatively charged free $\mathrm{COOH}$ groups of the separate subunits did not produce any significant changes in their secondary structure and in their ability to bind to the native counterpart subunits while the specific hormonal function, but not the immunological activity, of the modified recombinants was completely lost. Recombinant of both modified subunits was completely inactive in immuno- and hormonal activity tests.

It may be concluded that the free $\mathrm{COOH}$-groups in sturgeon GTH are of exclusive importance for the hormone activity at the receptor level as the bearers of the negative charge in the specific effector zones are located on the surface of the hormone molecule.

\section{ACKNOWLEDGEMENTS}

This work was supported by the Latvian Council of Science, grants 05.1412 and 05.1791.

\section{REFERENCES}

Faith, M.R., Pierce, J.G. (1975). The carboxylic acid groups of bovine luteinizing hormone. (The effect of their modification on receptor site binding and subunit-subunit interaction). J. Biol. Chem., 250(17), 6923-6929. 
Hennen, G., Prusik, Z., Maghuin-Rogister, G. (1971). Porcine luteinizing hormone and its subunits. Eur. J. Biochem., 18, 376-383.

Lees, J.G., Miles, A.J., Wien, F., Wallace, B.A. (2006). A reference database for circular dichroism spectroscopy covering fold and secondary structure space. Bioinformatics, 22(16), 1955-1962.

Ouchterlony, O. (1958). Diffusion-in-gel methods for immunological analyses. Progr. Allergy, 5, 1-6.

Sreerama, N., Venyaminov, S.Y., Woody, R.W. (1999). Estimation of the number of alpha- helical and beta-strand segments in proteins using circular dichroism spectroscopy. Protein Sci., 8, 370-380.

Thornton, V.F. (1971). A bioassay for progesterone and gonadotropins based on meiotic division of Xenopus oocytes in vitro. Gen. Comp. Endocrinol., 16, 599-605.

Whitmore, L., Wallace, B. A. (2004). DICHROWEB, an online server of protein secondary structure analyses from circular dichroism spectroscopic data. Nucleic Acid Res., 32, W668-W673.

Zenkevičs, H. (1994). Fish gonadotropic hormone: Structural-functional investigations. Proc. Latvian Acad. Sci., Section B, 48(5/6), 82-88.
Zenkevičs, H., Vose, V., Būcena, A. (1999). Substitution of native subunits in sturgeon gonadotropin. Proc. Latvian Acad. Sci., Section B, 53(5), 261-264.

Zenkevičs, H., Vose, V., Būcena, A. (2003). Functional role of tryptophan residues in sturgeon gonadotropic hormone. Proc. Latvian Acad. Sci., Section B, 57(5), 187-190.

Зенкевич Г. А. (1992). Гонадотропный гормон рыб: получение и свойства [Fish Gonadotropic Hormone: Isolation and Properties]. Рига, Зинатне. 224 с. (in Russian).

Зенкевич Г. А., Арбатский Н. П., Сланке В. П., Желтова А. О., Деревицкая В. А. (1992). Структура углеводных цепей димерной молекулы и отдельных субъединиц гонадотропина русского осетра [Structure of the carbohydrate chains of the dimeric molecule and individual subunits of the Russian sturgeon gonadotropin]. Биоорганическая химия, 18, 226-234 (in Russian).

Зенкевич Г, А., Сланке В. П., Лаце З. М., Кирстукас И. П. (1987). Свойства субъединиц как компонентов антигенной структуры гонадотропина осетра [Properties of sturgeon gonadotropin subunits as the components of the hormone antigenic structure]. Доклады Академии Наук СССР, 297, 1480-1482 (in Russian).

Received 25 October 2007

\section{KARBOKSILGRUPU LOMA STORU GONADOTROPĪNA OTRĒJĀ STRUKTŪRĀ UN FUNKCIJĀ}

Brīvās negatīvi uzlādētās karboksilgrupas tika selektīvi k̦īmiski modificētas (neitralizētas) storu gonadotropā hormona $\alpha$ un $\beta$ subvienībās. Vienpadsmit brīvās karboksilgrupas, trīs $\alpha$ un astoṇas $\beta$ subvienībā, tika modificētas ar glicīna etilēsteri karbodiimīda klātbūtnē. Reasociētie $\alpha-\beta$ dimēri (rekombinanti), kas saturēja vienu vai abas modificētās subvienības, neuzrādīja specifisko hormonālo aktivitāti, kamēr to imūnreaktivitāte bija jūtami pazemināta salīdzinājumā ar standartsubvienību rekombinantu (kontroli). CD spektroskopijas pētījumi parādīja, ka modifikācija nerada būtiskas izmaiņas atsevišķu subvienību otrējā struktūrā. Secināts, ka brīvās karboksilgrupas kā negatīvā lādiņa nesējas ir nepieciešamas hormona aktivitātei un tām ir svarīga loma hormona funkcijā membrānreceptoru līmenī. 